\title{
Explaining the Natural Materials of Traditional Kitchen Appliances In the Javanese Coastal Communities Based on Internal Structure Formation of Lingual Units
}

\author{
M. Suryadi ${ }^{1, *}$ and Riris Tiani ${ }^{1}$ \\ ${ }^{1}$ Department of Indonesian Literature, Faculty of Humanities, Diponegoro University, Semarang - Indonesia
}

\begin{abstract}
The purpose of this study is to describe the traditional kitchen appliances used by Javanese women. This explanation is based on deciphering its shape and structure, and semantic deciphering. The natural materials used are always environmentally friendly and have a trustworthy charge that can be delivered transparently or clandestinely, The research method used was descriptive qualitative. The methods of collecting the used data were observation, and in-depth interviews. The method of research analysis was by decomposing the lingual unit component of the traditional kitchen lexicon compiler from the derivative word into a basic form by utilizing the technique direct divide elements in the units of form and meaning. The findings of the research are the rules of forming lingual units for traditional kitchen appliances from the basic forms to derivative forms. The rules of formation in the word formation are produced by lexicon reconstruction, while the rules of formation in the meaning field are generated by semantic developers originating from coastal culture. The description of natural material based on the analysis of the internal structure of lingual units is obtained by the coherence of circular relations: sign-concept-functions-cultural values-sign.
\end{abstract}

Keywords: natural materials; traditional kitchen; Javanese; lingual units.

\section{Introduction}

Javanese people have cultural diversity; each cultural element is stored in the noble values and philosophy of the nature of life. Those values and philosophies as the characters attach in every movement of life which are both in concrete and verbal. Thus, every result of Javanese people's efforts is always bound by nobility and harmony with nature. The nobility of Javanese society is embedded in the Javanese social order and institutions. Meanwhile, the harmony with nature is embedded in the management and utilization of the surrounding environment.

Judging from the symbiotic phenomenon between Javanese peoples and their surrounding nature is reflected in the utilization of natural products processed by Javanese people from generation to generation, both in the form of processed equipment and processed materials. The processed equipment that is used considers three aspects, namely aspects of benefit, aspects of health, and aspects of environmental preservation. While the processed materials pay attention to five aspects, namely aspects of material strength, aspects of savings, aspects of the calculation of the season, and aspects of the age of the material.

The accuracy in considering aspects of life indicates that javanese society always acts cautiously, considers the good and bad, and demands harmony with nature.
All of the actionsof the Javanese people are recorded and photographed in naming cultural results, including processed materials and processed equipment. This research focuses more on the study of Javanese processed tools stored in traditional kitchen utensils. The formulation of the problem on which this research is based is how to decompose the lingual unit structure that is attached to processed tools made from materials on traditional Javanese coastal kitchen utensils.

\section{Literature Review}

The traditional tool of coastal Javanese people uses more natural materials than metal. Natural materials that are often used as basic ingredients are bamboo stems. Bamboo trees (Gigantochloa) as tropical plants, flourish in Indonesia. The benefits of bamboo plants are very high, especially for the production of oxygen (health), infiltration of water, and have high commodity numbers as basic craft materials [1]. The processing of bamboo reeds into a craft is often followed and influenced by local wisdom. The strength of this local wisdom is able to withstand the scouring of technology so that the existence of bamboo handicrafts can be maintained [2]. The selection of bamboo as the basic material for making processing equipment always pays attention to the quality, including the determination of the age of

\footnotetext{
* Corresponding author: mssuryadi07@gmail.com
} 
bamboo and the type of bamboo. The determination of age and type of bamboo will affect the durability of tools and human health [3].

The local wisdom embedded in Javanese society is reflected in the behavior of everyday life so that the identity as a Javanese human being appears to be Njawani [4]. The value of local wisdom also provides a leading role in filling the quality of life, especially in seeing himself as one of the Javanese people who always emphasizes the noble in behavior [5].

Javanese women have an important role in household life, the dual role is more often done, and namely when certain roles as an economic administrator, while others are acting as a household pillar [6]. The division of women's roles in household nodes and political life is a manifestation of the strength of female characters [7].

The theoretical approach used in this study is sociolinguistics [8], [9], and [10] by considering the lingual phenomena stored in traditional Javanese coastal household appliances. The culture of Javanese, especially the culture of Coastal Java is a major consideration when deciphering the phenomenon of lingual units. Language and culture cannot be separated from one another, each lingual unit spoken will be photographed in its local culture, and on the contrary the culture that belongs to a society is reflected through its language [11] and [12].

\section{Research Methodology}

The location of the research was in Demak, Central Java. The type of research in this study is qualitative. The research approach used was sociolinguistics by considering the culture of coastal Javanese people. Research data is traditional household appliances The data collection methods used are observation and indepth interviews. The observation method is used to encompass the data related to the use of natural materials. The in-depth interview method is used to encompass the data related to traditional household tool identities. The identities of household appliances are in the form of lingual units, words and phrases. The analytical method used in this study is to break down the internal structure of words and phrases as traditional household appliances identities. The method used is direct element sorting which takes into account units of meaning and form. The meaning unit utilizes the field of meaning and value of philosophy. The form unit utilizes the classification of natural materials.

\section{Unraveling the Materials of Traditional Kitchenware in Coastal Java Communities Based on the Internal Structure of the Lingual Unit}

The Javanese people are known as a society that is obedient and respectful of Javanese culture and nature. This compliance is reflected in harmony toward the management of natural life cycle, including the selection of tools as a tool to simplify or ease their daily work.
Every natural material that is used as a life support tool is always chosen with consideration,whether it is from the aspects of benefits, aspects of health, aspects of value, even the aspects of conservation. Every aspect chosen has various considerations. These various considerations have values reflected in the naming unit in traditional Javanese kitchen utensils.

Traditional utensils or kitchen utensils in the Javanese community use a lot of basic materials from nature, both in the form of plants, rocks, and soil. In the study, this study focused more on natural plant materials.

\subsection{Pawon (Kitchen)}

Pawon or traditional Javanese kitchen as a place to lay, organize, and store all cooking utensils. The position or location of the Pawon in traditional Javanese house is always located at the back of the hoouse. Based on its location and function, pawon is often connected with kiratabasa: apa-apa awon ' a place to store dirty things'. In addition, the word pawon is often reconstructed from the form of pa-awu-an, the basic lexicon $a w u$ that means ash (Javanese: $a w u$ ) and the prefix $\{p a-\}$, suffix $\{-a n\}$ has a locative/place grammatical meaning, so Pawon is a place of awu or ash or cooking place.

Pawon in the life of the Javanese people has a variety of views, namely (1) the symbol of prosperity symbolized by Dewi Sri, (2) the symbol of women, because pawon is often identified with women's activities, the realm of women's activities in enforcing household economics, (3) symbol of stove, so that the synonym of the Pawon name appears, that is keren, dhingkel, luweng, and anglo. Each of these names remains core as a cooking processing tool. However, it still has differences, especially from the manifestation of its physical form. The differences are as follows. Dhingkel is a furnace made of bricks or stones which have one hole above. Luweng is a furnace with a longer shape that has more than one hole, generally three holes; the fuel is dry wood bars. Keren is a one-hole furnace with basic material in the form of river stone or brick, its shape is smaller than dhingkel, and the fuel is made from coconut shell. Anglo is a furnace made from clay which has undergone a processing process, the fuel used is charcoal.

\subsection{The Traditional Kitchen Tools Made from Natural Bamboo}

In harmony with the comprehensiveness, the traditional kitchen utensils (pawon) have tools or cooking utensils. The basic ingredients of these devices can be categorized into four basic ingredients, namely (1) plant materials, (2) stone materials, (3) metal materials, and (4) soil materials.

The plant material can still be categorized into three, namely bamboo trees, coconut trees, and hardwood tree materials. Bamboo material tends to be used as a container (static), while coconut tree and wood materials tend to be used as tools (of a dynamic nature). Tools derived from bamboo, for example: kukusan, tipas, besek, tampah, dunak, tumbu. Tools derived from 
coconut trees, for example beruk, kelud, sapu, siwur. Tools made from hardwood tree materials, for example lumping, irus, entong. This research study focuses more on the pawon tools made from bamboo reeds.

\subsection{Made from Bamboo Reed}

Traditional kitchen utensils made from reeds / bamboo stems are more dominant, compared to other ingredients. Bamboo reed material has an elastic texture. Materials from bamboo stems can be used entirely, whether it is from the bamboo skin, bamboo flesh, and bamboo segments. Bamboo reed tools have advantages in processing and matting; even in terms of quality of materials also have advantages. Tool materials made of bamboo, as follows.

\subsubsection{Winnowing Tray}

Winnowing Tray (tampah) is a traditional kitchen utensil made from bamboo reeds, namely bamboo skin or bamboo flesh, and bamboo culms. Bamboo skin patterns are woven together tightly and are perfectly circular and symetric, the sides are limited by bamboo hemispheres that are 7 or $9 \mathrm{~cm}$ high. Each side of the bamboo skin incision is tied in a circular direction inward. Small size tampah is called tebok. In Javanese cultural life, often appear the expression mbulane gedhe saktampah or mbulane bunder kaya tebok.

Woven bamboo on Tampah has a smooth texture, flexible and light. Tampah is used as a tool to clean the rice from the remnants of the dirt as a result from selepan by moving it in a rotating direction (nampini rice), so that all the dirt can separate and pull over, then discarded by flexing the tampah.

The lexicon of tampah can be parsed based on its formation analogy process, that is from the basic lexicon tampa 'accept', in the form of a verb it becomes nampa 'receive', that is to accept or place rice to be cleaned so that it can be separated between clean rice and its waste. The cleaning process is with circular movements or cakra manggilingan 'rotating movement'. With this rotating motion, you will be able to separate the rice that is clean and good against the dirt. This process symbolizes that the life of the Javanese man must be relieved (dhadha tampah) in order to sort out the good / clean side of life to the dark side of life. When it is reached, the aura of the Javanese man is like tampah, which is the bright symbol of the full moon (gedhene saktampah).

\subsubsection{Steaming}

Steaming (kukusan) is parts of traditional household utensils made from the basic ingredients of bamboo skin incisions. Kukusan is a woven cone with hollow woven type. The materials of kukusan are selected from the skin of bamboo with the consideration that steaming as a tool or tool for cooking rice, which is always in contact with hot / boiling water. Bamboo skin is more often exposed to hot water will change the color of the steaming streaks increasingly shiny yellow.

The kukusan lexicon means steam or smoke from boiling water. It is through this fumigation of hot water that rice can be converted into fluffy rice, because hot steam can spread on all sides of the steamer. Another function of kukusan is making rice cone. The creation of cooking rice with steaming models is a characteristic of Javanese culture. Another function of kukusan for the Javanese community is to cover the barrel.

\subsubsection{Bamboo Bucket}

Bamboo bucket (besek) is a traditional household tool made from woven bamboo incisions, used to store goods or human needs. Besek is always made in pairs, one function as a container, while the other functions as a cover. The shape of the besek is rectangular. The making of besek always in pairs has the meaning that life in the Javanese family must complement or mutually cover up the family's shame. The lower part or small besek is analogous to women (wedok) while the upper part or large besek is analogous to men (lanang) who must protect women, so that besek is always made in pairs.

\section{The Philosophy of Bamboo toward the Life of Javanese People}

Bamboo trees are always attached in Javanese life. The history and benefits of bamboo trees cannot be separated from the history of Javanese human life. Multipurpose bamboo trees in the utilization, inherent from the symbols attached to the bamboo tree itself. Some of the symbols of bamboo trees that are attached to the side of Javanese cultural life, can be traced to the description of bamboo clumps, bamboo roots, and bamboo stems, as follows.

Bamboo clumps as a symbol of the familiarity of the Javanese people. Bamboo trees always grow in the form of clumps. Javanese people often say dapuran pring, all types of bamboo trees (pring apus, pring jawa, pring petung, pring wulung, pring kuning) always grow in groups in the form of clumps, each root of fibers intertwining grows into strength. This form of clump is used as a symbol of harmony and strength.

Bamboo root as a symbol of connection or friendship or harmony. Bamboo roots that stick out sideways (fiber roots), bamboo roots make a strong bond to each other, closing every empty gap. This bamboo root is used as a tight bond, a kinship bond, a love bond that always covers the shortcomings of others, so it is very difficult to separate from one another.

Bamboo stems have a high philosophical value for the life of the Javanese. Bamboo stems that are towering straight as a symbol that Javanese humans must have high dreams (kagayuhan sing duwur), honest and straight-hearted, compose strong strength so they can stand tall. Old, young bamboo stems and shoots symbolize the life span of every human being. Human age if it's time to face God (Gusti ingkang maringi jagat) does not know old age (like old bamboo), young age 
(like young bamboo), and toddler age (like bamboo shoots). This philosophy is more commonly known as the phrase ngelmu pring.

The most popular ngelmu pring in Javanese society, is manungso iku urip ibarat kaya wit pring ora gampang tugel merga iso melur, ojo podo kaku, ojo mangumangu, tansah melur lan pasrah lan mlaku. As a Javanese who lives in Javanese culture and society, is not easily discouraged, continues to live an existing life and is full of gratitude, may not win himself, must not stand idly by but must fight maximally and optimally.

In the industrial era, Javanese people began to return to nature. All equipment used in daily life is prioritized that is friendly to the environment. When the environment is maintained, life becomes healthier. A healthy and smart young generation will be born.

\section{Conclusion}

Lingual units that are attached to traditional Javanese traditional tools have benefits aspects, health aspects, value aspects, and conservation aspects. These aspects are mutually reinforcing in the form of braid. Each braid supports other links. Benefits aspects: traditional tools made from natural bamboo, provide great benefits to health, which is protected from metal contamination. In terms of environmental conservation, many Javanese people have developed bamboo trees in riverbank areas to avoid erosion or scouring of water. Aspects of value and philosophy that the traditional kitchen utensils made from bamboo are like learning to ngelmu pring, which is life cannot be broken and stiff but must be flexible like a bamboo tree. Lingual units attach in traditional kitchen utensils can be traced to historical values (diachronic) because Javanese culture is always reflected and attached to lingual units as a basic identity.

\section{References}

1. E. Arsad, Teknologi Pengolahan dan Manfaat Bambu, J. Ris. Ind. Has. Hutan (2015)

2. I. Yeny, D. Yuniati, and H. Khotimah, Kearifan Lokal dan Praktik Pengelolaan Hutan Bambu pada Masyarakat Bali, J. Penelit. Sos. dan Ekon. Kehutan. (2016)

3. Z. R. Ahmad, Kasmudjo, R. Pujiarti, and S. Sunarta, Pengaruh Perbedaan Jenis dan Umur Bambu terhadap Kualitasnya sebagai Bahan Mebel dan Kerajianan, Peran. dan Strateg. Kebijak. Pemanfaat. Has. Hutan Bukan Kayu dalam Meningkat. Daya Guna Kaw. (Hutan). Pros. Semin. Nas. (2015)

4. Ni Wayan Sartini, Menggali Nilai Kearifan Lokal Budaya Jawa Lewat Ungkapan (Bebasan, Saloka, dan Paribahasa), Universitas Airlangga (2009)

5. T. P. Utomo and S. Subiyantoro, Nilai Kearifan Lokal, Humaniora (2012)

6. S. Nakagawa and K. Suwa, A cultural approach to recovery assistance following urban disasters, City, Cult. Soc. (2010)

7. P. M. Lal Coveney, Margaret Jackson, Sheila Jeffreys, and Leslie Kay, The Sexuality Papers Male
Sexuality and the Social Control of Women, 1st Editio. London: Routledge (2019)

8. G. Van Herk, Sociolinguistics, in International Encyclopedia of the Social \& Behavioral Sciences: Second Edition (2015)

9. M. Meyerhoff, Introducing Sociolinguistics (2018)

10. J. Aitchison and R. Wardaugh, An Introduction to Sociolinguistics, Br. J. Sociol (2007)

11. N. Bonvillain, Language, culture and communication: The Meaning of Messages (2011)

12. H. F. Schiffman, Linguistic Culture and Language Policy (2010) 